\title{
Nickel Alloy Catalysts for the Anode of a High Temperature PEM Direct Propane Fuel Cell
}

\author{
Shadi Vafaeyan, ${ }^{1,2}$ Alain St-Amant, ${ }^{3}$ and Marten Ternan ${ }^{4}$ \\ ${ }^{1}$ Chemical and Biological Engineering, University of Ottawa, Ottawa, ON, Canada K1N 6N5 \\ ${ }^{2}$ Centre for Catalysis Research and Innovation, University of Ottawa, Ottawa, ON, Canada K1N 6N5 \\ ${ }^{3}$ Department of Chemistry, University of Ottawa, Ottawa, ON, Canada K1N 6N5 \\ ${ }^{4}$ EnPross Inc., 147 Banning Road, Ottawa, ON, Canada K2L 1C5
}

Correspondence should be addressed to Marten Ternan; ternan@bell.net

Received 26 February 2014; Accepted 26 April 2014; Published 26 June 2014

Academic Editor: Albert Demonceau

Copyright (C) 2014 Shadi Vafaeyan et al. This is an open access article distributed under the Creative Commons Attribution License, which permits unrestricted use, distribution, and reproduction in any medium, provided the original work is properly cited.

\begin{abstract}
High temperature polymer electrode membrane fuel cells that use hydrocarbon as the fuel have many theoretical advantages over those that use hydrogen. For example, nonprecious metal catalysts can replace platinum. In this work, two of the four propane fuel cell reactions, propane dehydrogenation and water dissociation, were examined using nickel alloy catalysts. The adsorption energies of both propane and water decreased as the $\mathrm{Fe}$ content of $\mathrm{Ni} / \mathrm{Fe}$ alloys increased. In contrast, they both increased as the $\mathrm{Cu}$ content of $\mathrm{Ni} / \mathrm{Cu}$ alloys increased. The activation energy for the dehydrogenation of propane (a nonpolar molecule) changed very little, even though the adsorption energy changed substantially as a function of alloy composition. In contrast, the activation energy for dissociation of water (a molecule that can be polarized) decreased markedly as the energy of adsorption decreased. The different relationship between activation energy and adsorption energy for propane dehydrogenation and water dissociation alloys was attributed to propane being a nonpolar molecule and water being a molecule that can be polarized.
\end{abstract}

\section{Introduction}

In principle, all types of fuel cells can convert the chemical energy of fuel into electrical energy more efficiently than competing technologies such as batteries or combustion processes. We have been investigating fuel cells that use hydrocarbons fuels (natural gas for urban areas and liquefied petroleum gas, LPG, for rural areas) that react directly at the anode of the fuel cell. Direct hydrocarbon fuel cells, DHFCs, have several advantages over hydrogen or methanol fuel cells. Theoretically, hydrocarbon fuels can be even more energy efficient than either hydrogen or methanol. Storage of liquid hydrocarbons is technologically less complex and less costly compared to that for hydrogen gas. The cost of delivering conventional electrical power in rural areas is about an order of magnitude greater than in urban areas, even though the price charged for electrical power is similar. Therefore, a greater capital cost for fuel cells can be justified for rural areas compared to urban areas. For that reason, we are investigating
DHFCs that operate on propane fuel, because infrastructure for its delivery currently exists in many rural locations. Despite their many advantages, DHFCs have one substantial drawback. They have much smaller current densities (reaction rates) than fuel cells using hydrogen or methanol.

There are three reviews [1-3] that describe the extensive research done on DHFCs during the 1960s. Because that research did not produce the improvement in technology that was wanted, interest in the topic diminished, although research has continued to the present time [4-9]. Our group's strategy includes fuel cell reactor modeling using computational fluid dynamics, CFD [10-12], and fuel cell catalyst modeling using density functional theory (DFT) [13, 14]. More recently, we have also been performing experimental work.

Our research is directed toward the development of high temperature polymer electrolyte membrane, PEM, fuel cells operating near $120^{\circ} \mathrm{C}$. In contrast, conventional PEM fuel cells operate near $80^{\circ} \mathrm{C}$. One of the principal advantages of 
a $120^{\circ} \mathrm{C}$ operation is the elimination of liquid phase water. In the presence of water in the liquid phase, $\mathrm{Pt}, \mathrm{Ir}, \mathrm{Au}$, and $\mathrm{Pd}$ are the only metals that are stable in such an acidic environment at +0.8 to $+1.0 \mathrm{~V}[15]$. The absence of liquid water corrosion from the accumulation of acidic species is diminished, so that the platinum group metals normally used as catalysts might be replaced by less expensive metals. Examples would be the catalysts used in alkaline fuel cells, nickel (at the anode), and silver (at the cathode). When the temperature of the Nafion electrolyte used in conventional PEM fuel cells is increased from 80 to $120^{\circ} \mathrm{C}$, its proton conductivity decreases by an order of magnitude. Our experiments [16-18] suggest that a modified zirconium phosphate electrolyte supported in a porous polytetrafluoroethylene membrane may be appropriate for $120^{\circ} \mathrm{C}$ operation of direct hydrocarbon fuel cells.

The overall reaction in a direct propane fuel cell is shown in (1). The reaction at the anode is shown in (2), where EYL represents the electrolyte and Me represents the solid transition metal electrocatalyst that in this work is either a $\mathrm{Ni}-\mathrm{Fe}$ alloy or a Ni-Cu alloy. The cathode reaction shown in (3) has been studied extensively by others [19-21] and is not part of this work. Consider the following:

$$
\begin{gathered}
\mathrm{C}_{3} \mathrm{H}_{8}+5 \mathrm{O}_{2}=3 \mathrm{CO}_{2}+4 \mathrm{H}_{2} \mathrm{O} \\
\mathrm{C}_{3} \mathrm{H}_{8}(\mathrm{~g})+6 \mathrm{H}_{2} \mathrm{O}(\mathrm{g}) \\
\longrightarrow 3 \mathrm{CO}_{2}(\mathrm{~g})+20 \mathrm{H}^{+}(\mathrm{EYL})+20 \mathrm{e}^{-}(\mathrm{Me}) \\
5 \mathrm{O}_{2}+20 \mathrm{H}^{+}(\mathrm{EYL})+20 \mathrm{e}^{-}(\mathrm{Me})=10 \mathrm{H}_{2} \mathrm{O}
\end{gathered}
$$

The anode reaction includes a single electrochemical reaction plus a multistage reaction network of chemical reactions (dehydrogenation of adsorbed $\mathrm{C}-\mathrm{H}$ species, water dissociation, hydroxylation of adsorbed carbon species, and carbon-carbon bond cleavage) through which production of a number of intermediate by-products (such as propanol, propionaldehyde, propionic acid, ethanol, acetaldehyde, acetic acid, methanol, formaldehyde, formic acid, carbon monoxide, and carbon dioxide) is possible.

The initial steps of the chemical reaction network at the anode, (4) and (5), were

$$
\begin{gathered}
\mathrm{C}_{3} \mathrm{H}_{8}=\mathrm{C}_{3} \mathrm{H}_{7}+\mathrm{H} \\
\mathrm{H}_{2} \mathrm{O}=\mathrm{H}+\mathrm{OH} \\
\mathrm{H}=\mathrm{H}^{+}+\mathrm{e}^{-}
\end{gathered}
$$

the ones studied in this work. The single electrochemical reaction (6) that occurs is the ionization of hydrogen atoms where the hydrogen atoms can be formed via either (4) or (5). Of the 20 protons produced in the stoichiometric reaction at the anode (2), 8 come from the propane molecule and 12 are derived from water. Therefore, (5) is an important reaction.

A number of DFT studies on various fuel cell reactions have been reported in the literature. Some examples are as follows: the oxygen electroreduction reaction [22], the hydrogen electrooxidation reaction in hydrogen fuel cells [23], the electroreduction reaction in the presence of liquid water [24], and the methanol electrooxidation reaction in methanol fuel cells [25]. The synergy between computational studies and experimental studies for fuel cells has been described recently [26].

The focus of this work has been on the use of metal alloys as anodic catalysts capable of the various reaction steps in the propane electrooxidation process. There are many studies investigating metal alloys as electrocatalysts in fuel cells, including the following topics: an anode material for low temperature fuel cells [27], carbon poisoning of cathode electrocatalyst alloys in SOFCs [28], the effect of the electrocatalyst on the oxygen reduction reaction $[29,30]$, and anodic methanol electrooxidation reaction on clusters of 2 nd and 3rd row group VIII transition metals and Pt-Ru alloys [31].

The objective of this work was to investigate nickel metal and nickel alloys as possible anodic catalysts by performing DFT computations. Nickel, copper, and iron are 3D nonprecious metals. Various compositions of $\mathrm{Ni} / \mathrm{Fe}$ and $\mathrm{Ni} / \mathrm{Cu}$ alloys were examined for both the propane dehydrogenation reaction and the water dissociation reaction.

\section{Methods and Computations}

SIESTA software based on Kohn-Sham density functional theory was used to perform quantum chemical computations by Soler et al. [32]. The generalized gradient approximation (GGA) method was used as the exchange correlation functional type, with Becke-Lee-Yang-Parr (BLYP) parameterization. The default basis set, a double- $\zeta$ polarization set composed of a compact and a diffused orbital basis, was used in these calculations. The tolerance of the density matrix was set to $10^{-3}$. This value sets the maximum allowable difference between the output and the input on each element of the density matrix in a self-consistent field, SCF, cycle. A $4 \times 4 \times$ $4(4 * 4 * 4 / 2=32 k$-points $)$ Monkhorst-Pack $k$-point mesh was used. The convergence as a function of the number of $k$-points was carefully monitored. Increasing the $k$-point mesh from $32 k$-points to $48 k$-points changed the adsorption energies by an insignificant amount $\left(\sim 4 \times 10^{-5} \mathrm{eV}\right.$ or $\sim 8 \times$ $10^{-3} \mathrm{~kJ} / \mathrm{mol}$ ). In some calculations, the coordinates of atoms were allowed to relax (change position) to determine the geometry having the minimum energy. When the difference in energy between successive calculations was less than $10^{-3} \mathrm{eV}$ and when the maximum atomic force was less than $0.01 \mathrm{eV} / \AA$, the convergence criteria were attained and the atomic geometry was optimized.

The pseudopotential for nickel was generated using the ATOM program of SIESTA. The Perdew-Burke-Ernzerhof (PBE) [33] exchange correlation was used for the generation of the electronic configuration. The improved TroullierMartins ( $t m 2$ ) method was used to generate the pseudopotential files for nickel, copper, and iron in their nonpolarized ground state electron configurations. The pseudopotential input file for a metal required that a particular core radius, $r_{c}$, be specified. It was obtained by trial and error. If the initial $r_{c}$ value was too small ( $\leq 1.5$ for metals used in this study), the pseudopotential could not be generated. After a value of $r_{c}$ that was slightly greater than the minimum acceptable value had been obtained, the software would generate an exact 
value for $r_{c}$. That $r_{c}$ value (3.34 Bohr for nickel, 3.18 Bohr for copper, and 3.64 Bohr for iron) was used to generate the pseudopotential. The pseudopotential output file was used for all subsequent computations that included that metal. To confirm the validity of our pseudopotential generation method and the resulting pseudopotentials, energy calculations were performed for a $\mathrm{Ni}$ unit cell using our custom generated $\mathrm{Ni}$ pseudopotential. The lattice constant (LC) that had the minimum total energy for the $\mathrm{Ni}$ unit cell was $0.370 \mathrm{~nm}$. It differs by $4.9 \%$ from the experimental LC for $\mathrm{Ni}(0.352 \mathrm{~nm})$ that was measured by X-ray diffraction, XRD; see Haynes [34]. This difference is smaller than the $6 \%$ error that was reported when using the PBE functional; see Perdew et al. [35].

DFT calculations were performed on a system of periodically repeated entities, defined in relation to nickel crystal unit cells. Each entity consisted of one propane molecule, a slab of nickel atoms, and a vacuum space. The slab consisted of two layers of atoms located on an $x-y$ plane. The cells were arranged as follows: 3 cells $\times 3$ cells with 4 atoms per cell $(3 \times$ $3 \times 4=36$ atoms per slab). The (100) surface was used for all nickel slabs. When calculations were performed with slabs containing $\mathrm{Cu}$ or Fe atoms, each $\mathrm{Cu}$ or Fe atom replaced a nickel atom in the original nickel slab. The vacuum space had a thickness of nine empty unit cells and was located above the nickel slab in the $z$ direction. The vacuum space occupied the distance from the upper surface of a nickel slab within one periodic entity to the bottom surface of the next nickel slab above it in the next periodic entity. Ideally, the vacuum layer can prevent or minimize interactions between the periodic entities in the direction perpendicular to the surface. The choice of slabs with 36 nickel atoms per slab is typical of the number of metal atoms in many DFT slab calculations [3639].

The slab surface should be large enough, in relation to the surface species to avoid both (a) interactions between the surface species on one slab and the nickel atoms in neighbouring slabs and (b) adsorbate-adsorbate interactions. Because there were 18 atoms in the surface of our slabs, the fractional surface coverage of propane was less than 0.2 . It has been shown by Grabow et al. [40] that adsorbate-adsorbate interactions can influence the binding energy by as much as $1 \mathrm{eV}$ when the fractional surface coverage increases from 0.2 to 1 . Our low surface coverage minimized adsorbate-adsorbate contributions to the adsorption energy.

To confirm that the slabs were thick enough to predict propane adsorption on $\mathrm{Ni}(100)$, the thickness of the slabs was increased from 2 atoms to 4 atoms (increasing the number of atoms per slab from 36 to 72 ). The increased slab thickness only changed the value of the propane adsorption energy by $7.3 \%(\sim 0.04 \mathrm{eV}$ or $\sim 4 \mathrm{~kJ} / \mathrm{mol})$. This relatively small variation indicates that calculations using slabs having two layers of atoms are sufficiently accurate to qualitatively predict trends in propane adsorption energy.

Another single adsorption energy calculation for propane was performed on a 2-layer $\mathrm{Ni}(100)$ slab in which the bottom layer was fixed at the positions of bulk nickel and the top layer was allowed to relax. When compared to the calculation in which the atoms in both layers were allowed to relax, the change in energy was also very small $\left(4 \times 10^{-4} \mathrm{eV} \sim\right.$ $0.04 \mathrm{~kJ} / \mathrm{mol}$ ).

The adsorption energies $\left(E_{\mathrm{ads}}\right)$ of the adsorbates (initially adsorbed reactants and subsequent adsorbed intermediate species) on the metal slabs were calculated according to the following equation:

$$
E_{\text {ads }}=\left(E_{\text {adsorbate }+ \text { slab }}\right)_{\mathrm{MIN}}-E_{\text {species }}-E_{\text {slab }},
$$

where $E_{\text {adsorbate+slab }}$ is the total energy for the adsorbate plus metal slab and $\left(E_{\text {adsorbate+slab }}\right)_{\text {MIN }}$ is the total energy for the configuration of the adsorbate plus metal slab that has the minimum energy, $E_{\text {species }}$ is the energy of an isolated reactant molecule in the gas phase, $E_{\text {slab }}$ is the energy for a metal slab, and $E_{\text {ads }}$ is the energy for adsorption of the species on the surface of the metal slab (or heat of adsorption).

The transition state energy, $\Delta E_{\mathrm{TS}}$, for each reaction was obtained by calculating $E_{\text {adsorbate+slab }}$ as a function of the $\mathrm{C}-\mathrm{H}$ bond length, the $\mathrm{C}-\mathrm{O}$ bond length, or the $\mathrm{O}-\mathrm{H}$ bond length. For each $E_{\text {adsorbate+slab }}$ calculation, the $\mathrm{C}-\mathrm{H}$ bond length, the $\mathrm{C}-\mathrm{O}$ bond length, or the $\mathrm{O}-\mathrm{H}$ bond length was maintained constant, while all other bond lengths and all bond angles in the adsorbed species were relaxed to obtain the adsorbate configuration having the minimum energy for that particular $\mathrm{C}-\mathrm{H}$ bond length, $\mathrm{C}-\mathrm{O}$ bond length, or $\mathrm{O}-\mathrm{H}$ bond length. Subsequently, the resulting energies that had been calculated at each $\mathrm{C}-\mathrm{H}$ bond length, $\mathrm{C}-\mathrm{O}$ bond length, or $\mathrm{O}-\mathrm{H}$ bond length were compared as a function of their bond lengths. The configuration of the adsorbed species having the maximum energy, $\left(E_{\text {adsorbate+slab }}\right)_{\mathrm{MAX}}$, was the transition state (TS).

The transition state energies were obtained using the following equation:

$$
\Delta E_{\mathrm{TS}}=\left(E_{\text {adsorbate+slab }}\right)_{\mathrm{MAX}}-\left(E_{\text {adsorbate+slab }}\right)_{\mathrm{MIN}} .
$$

Variations in the electrical potential of the slabs were not considered (zero electric field).

\section{Results and Discussion}

Figure 1 shows the top view of the optimized structures of propane adsorbed on Ni/Fe alloy slabs. Propane is adsorbed in a somewhat similar manner on all of the $\mathrm{Ni} / \mathrm{Fe}$ alloy slab surfaces. As the $\mathrm{Ni} / \mathrm{Fe}$ atomic ratio decreases, the alignment of the three carbon atoms in the propane molecule becomes somewhat tilted with respect to the parallel rows of the metal atoms. The greatest tilt in alignment is on the surface of the pure Fe slab. Both Ni and Fe have fourfold symmetry but their crystal structures are different. Ni has a face-centered cubic, fcc, structure while Fe has a body-centered cubic, bcc, structure. In the first three images in Figure 1, the slabs have an fcc structure where the $\mathrm{Fe}$ atoms have replaced $\mathrm{Ni}$ atoms in that structure.

The propane adsorption energies are plotted in Figure 2 as a function of the Fe content in the slab. The energy of adsorption, $E_{\mathrm{ads}}$, goes through a minimum as the Fe content of the slab increases. The diamond shaped data points represent alloys having ordered structures that have been defined. The diamond shaped datum point at $2.8 \% \mathrm{Fe}$ is for a slab in which one of the $\mathrm{Ni}$ atoms has been replaced with an $\mathrm{Fe}$ 


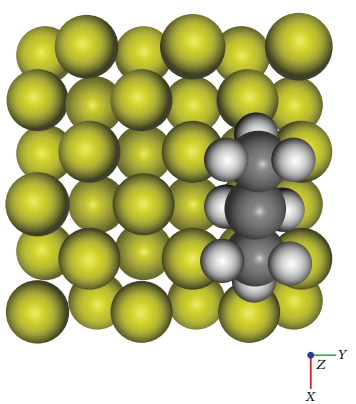

(a)

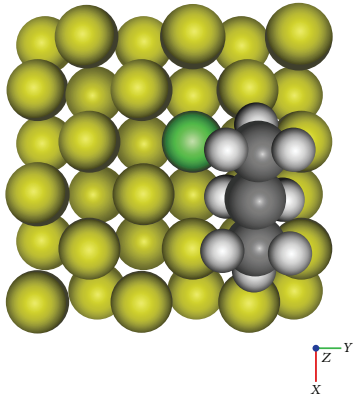

(b)

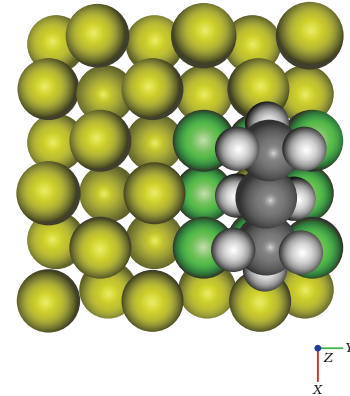

(c)

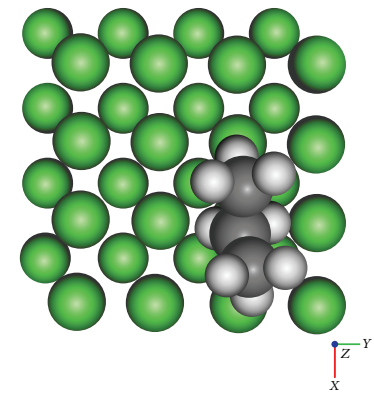

(d)

Figure 1: Propane adsorbed on the surface of Ni/Fe alloy anode slab (top view) with compositions of (a) $0 \%$ Fe (pure Ni slab), (b) $2.8 \%$ Fe, (c) $22.2 \% \mathrm{Fe}$, and (d) $100 \% \mathrm{Fe}$.

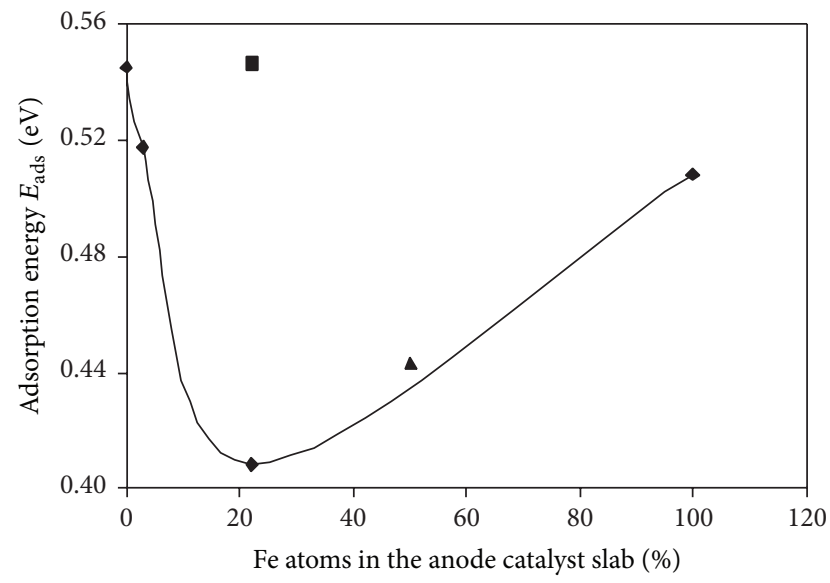

FIGURE 2: DFT calculated adsorption energies of propane on the surface of $\mathrm{Ni} / \mathrm{Fe}$ alloy slabs with various compositions. The diamond shaped data points represent slabs having ordered structures. The triangular shaped datum point represents a slab containing $50 \% \mathrm{Ni}$ and $50 \% \mathrm{Fe}$. The square shaped datum point represents a $22.2 \% \mathrm{Fe}$ slab where the $8 \mathrm{Fe}$ atoms have arbitrary locations and are further from the Ni adsorption site.

atom that is adjacent to the $\mathrm{Ni}$ adsorption site, that is, the $\mathrm{Ni}$ metal atom on which the central carbon atom of the propane molecule is adsorbed. Even the presence of one Fe atom adjacent to the $\mathrm{Ni}$ adsorption site causes a small decrease in the adsorption energy. The diamond shaped datum point at $22.2 \mathrm{wt} \% \mathrm{Fe}$ is for a slab in which the eight nearest neighbors of the $\mathrm{Ni}$ adsorption site have been replaced by Fe atoms. In this case, the decrease in adsorption energy is much more pronounced.

The square datum point represents a slab of $22.2 \mathrm{wt} \% \mathrm{Fe}$ atom in which the $8 \mathrm{Fe}$ atoms have arbitrary locations in the slab. In this case, most of the Fe atoms are not close to the $\mathrm{Ni}$ adsorption site. The adsorption energy is similar to that of the pure Ni slab. This suggests that an Fe atom needs to be adjacent to the $\mathrm{Ni}$ adsorption site if it is to influence the adsorption energy.

The triangular datum point represents a slab in which one-half of the $\mathrm{Ni}$ atoms in each layer were replaced by $\mathrm{Fe}$

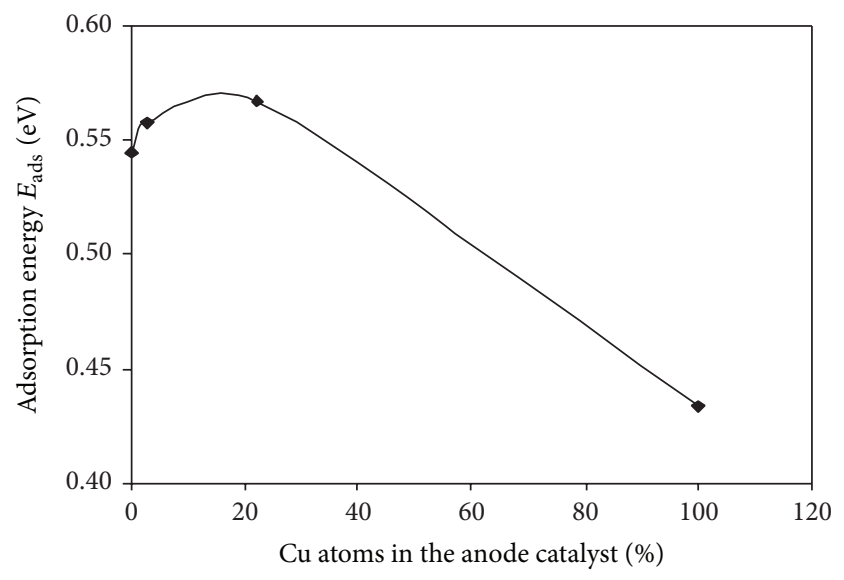

FIGURE 3: DFT calculated adsorption energies of propane on the surface of $\mathrm{Ni} / \mathrm{Cu}$ alloy slab with various compositions $(0 \% \mathrm{Cu}, 2.8 \%$ $\mathrm{Cu}, 22.2 \% \mathrm{Cu}$, and $100 \% \mathrm{Cu}$ ).

atoms. However, the Fe locations were arbitrary. The ordered structures represented by the diamonds may be considered to be "designer" adsorption sites. In contrast, the result for a $50 / 50 \mathrm{Ni} / \mathrm{Fe}$ alloy with arbitrary Fe atoms locations suggests that a specific location may not be important as long as there are a sufficient number of Fe atoms in the slab. It also suggests that a specialized technique for preparing the alloy may not be necessary.

In Figure 3, replacing $\mathrm{Ni}$ atoms in the slab by $\mathrm{Cu}$ (with the same ratios as the Ni/Fe alloy slabs) causes a maximum in adsorption energy as opposed to the minimum observed in Figure 2. The opposite effect may be related to the number of $\mathrm{d}$ electrons in the metal. Copper has one more d electron than nickel. In contrast, iron has two fewer d electrons than nickel.

The adsorption of water on four different Ni/Fe alloy slabs is shown in Figure 4. A slight change in orientation of the water molecule on the metal surface can be observed as the Fe content of the Ni/Fe alloy increases. The orientation of the water molecule on the $\mathrm{Fe}(100)$ surface is clearly different compared to that on the $\mathrm{Ni}(100)$ surface.

The water adsorption energies are plotted in Figure 5 as a function of the Fe content in the Ni-Fe alloy slab. As the Fe 


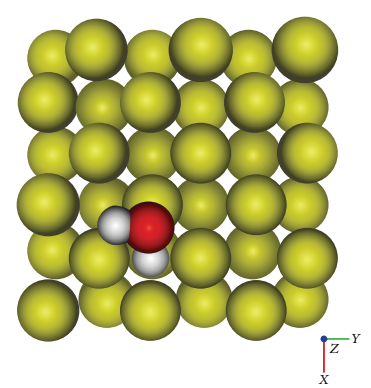

(a)

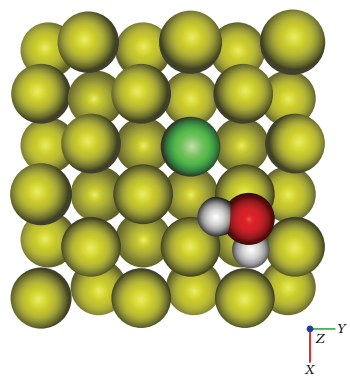

(b)

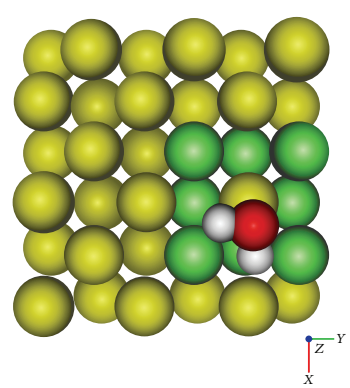

(c)

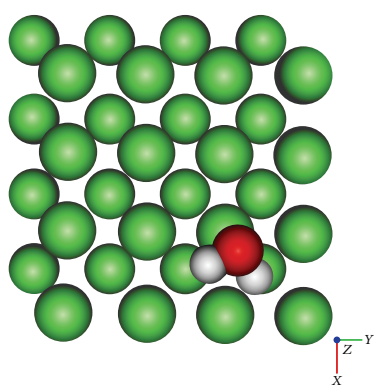

(d)

FIGURE 4: Water adsorbed on the surface of Ni/Fe alloy anode slab (top view) with compositions of (a) $0 \% \mathrm{Fe}$ (pure Ni slab), (b) 2.8\% Fe, (c) $22.2 \% \mathrm{Fe}$, and (d) $100 \% \mathrm{Fe}$.

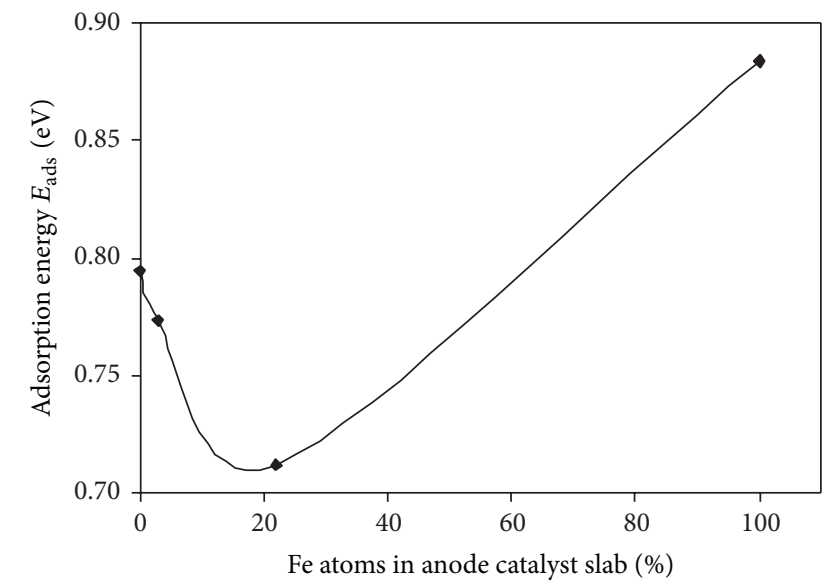

FIGURE 5: DFT calculated adsorption energies for water on the surface of NiFe alloy slab with various compositions ( $0 \% \mathrm{Fe}, 2.8 \%$ $\mathrm{Fe}, 22.2 \% \mathrm{Fe}$, and $100 \% \mathrm{Fe}$ ).

content of the slab increases, the energy of adsorption, $E_{\text {ads }}$, goes through a minimum. The shape of the plot is similar to the one for the adsorption of propane on $\mathrm{Ni} / \mathrm{Fe}$ alloys.

The water adsorption energies are plotted in Figure 6 as a function of the $\mathrm{Cu}$ content in the $\mathrm{Ni}-\mathrm{Cu}$ alloy slab. As the $\mathrm{Cu}$ content of the slab increases, the energy of adsorption, $E_{\text {ads }}$, goes through a maximum. The shape of the plot is similar to the one for the adsorption of propane on $\mathrm{Ni} / \mathrm{Cu}$ alloys.

The energy of adsorption appears to be a function of alloy composition. Both the propane and water adsorption plots have the same general shape for both $\mathrm{Ni} / \mathrm{Fe}$ and $\mathrm{Ni} / \mathrm{Cu}$ alloys. Changing the alloy composition from $\mathrm{Ni}$ to $\mathrm{Ni} / \mathrm{Fe}$ or from $\mathrm{Ni}$ to $\mathrm{Ni} / \mathrm{Cu}$ causes the same directional changes in energy of adsorption for both propane and water.

The activation energies for the dehydrogenation reaction of adsorbed propane to adsorbed propyl and atomic hydrogen species on Ni/Fe alloy slabs (with the same compositions used above for investigating the adsorption energies) were calculated using (5). The energy of a pure Ni slab plus its adsorbed species is shown in Figure 7 as a function of the $\mathrm{C}-\mathrm{H}$ bond distance. It is the distance from the propane central carbon atom, adsorbed on the Ni surface to the hydrogen atom being

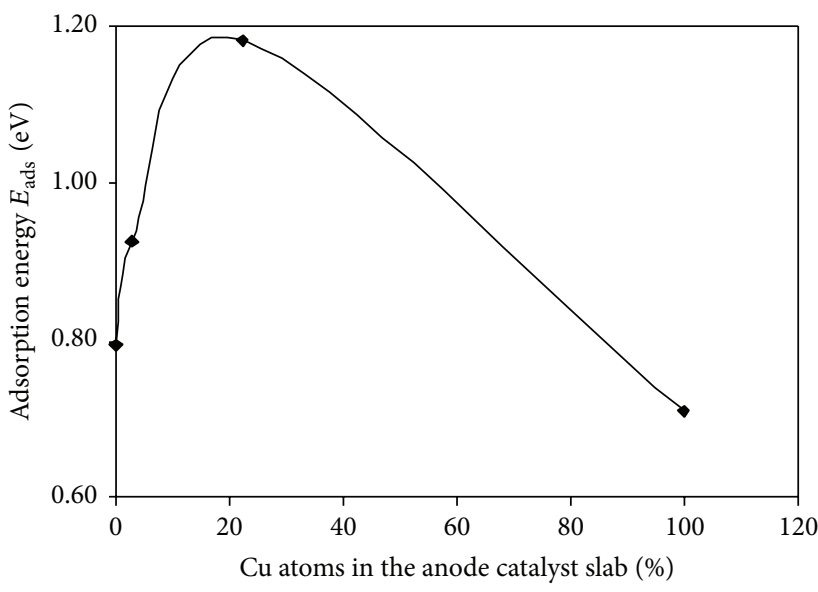

FIGURE 6: DFT calculated adsorption energies for water on the surface of $\mathrm{Ni} / \mathrm{Cu}$ alloy slabs having various compositions $(0 \% \mathrm{Cu}$, $2.8 \% \mathrm{Cu}, 22.2 \% \mathrm{Cu}$, and $100 \% \mathrm{Cu}$ ).

removed during the dehydrogenation reaction. The activation energy (barrier height) is the difference between the energy of the adsorbed state (the minimum energy near C$\mathrm{H}=0.11 \mathrm{~nm}$ ) and the transition state energy (the maximum energy near $\mathrm{C}-\mathrm{H}=0.17 \mathrm{~nm}$ ). Similar calculations were performed to determine the activation energies for propane dehydrogenation and water dissociation for the various $\mathrm{Ni} / \mathrm{Fe}$ and $\mathrm{Ni} / \mathrm{Cu}$ alloys.

The results for activation energy (energy barrier) calculations for propane dehydrogenation on slabs having different $\mathrm{Ni} / \mathrm{Fe}$ compositions are shown in Figure 8. As the Fe content of the slab increases, the activation energy goes through a maximum. Since the smallest activation energies are obtained with either pure nickel or pure iron, it appears that $\mathrm{Ni} / \mathrm{Fe}$ alloy catalysts are not helpful for propane dehydrogenation.

The activation energy for the water dissociation reaction is shown in Figure 9. There was a substantial decrease in activation energy as the Fe content in the Ni/Fe alloys increased. This indicates that $\mathrm{Ni} / \mathrm{Fe}$ alloy catalysts will be superior to pure $\mathrm{Ni}$ or pure $\mathrm{Fe}$ catalysts for the water dissociation reaction. The combined data in Figures 8 and 9 suggest that an ideal catalyst might contain domains of pure metal for 


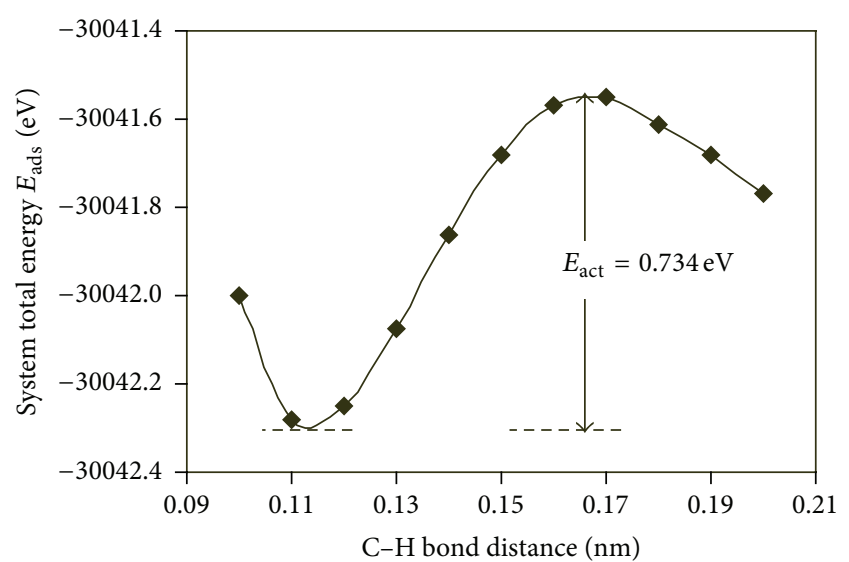

FIgURE 7: Energies of the adsorbate plus slab where the central carbon atom of the adsorbate had a defined $\mathrm{C}-\mathrm{H}$ bond length. All the other bond lengths and all the bond angles in the adsorbate were permitted to relax to those values that produced the minimum energy.

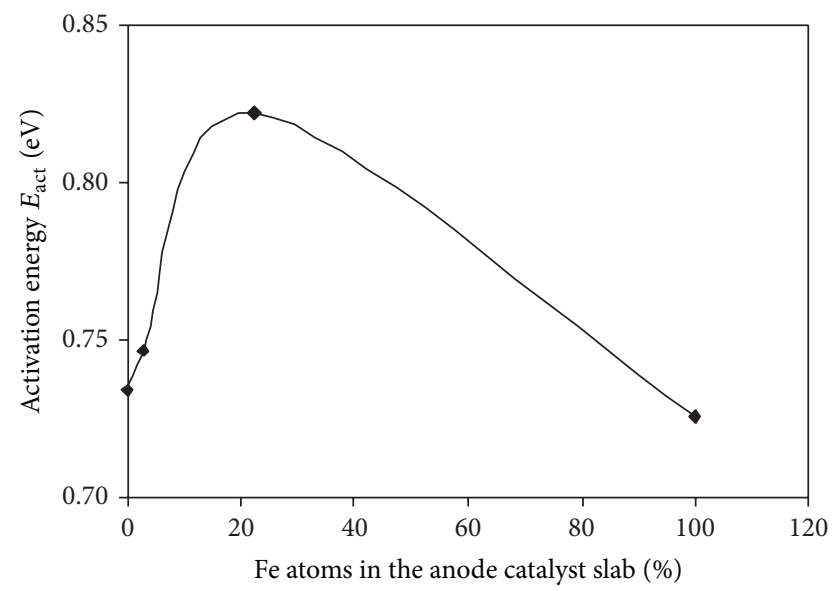

FIGURE 8: DFT calculated activation energy plot, $E_{\text {act }}(\mathrm{eV})$, for the dehydrogenation of propane; ${ }^{*} \mathrm{C}_{3} \mathrm{H}_{8} \rightarrow{ }^{*} \mathrm{C}_{3} \mathrm{H}_{7}+{ }^{*} \mathrm{H}$ ( ${ }^{*}$ indicating that the species is adsorbed on the surface of the catalyst) for various compositions of $\mathrm{Ni} / \mathrm{Fe}$ anode catalyst slabs ( $0 \% \mathrm{Fe}, 2.8 \% \mathrm{Fe}, 22.2 \%$ $\mathrm{Fe}$, and $100 \% \mathrm{Fe})$.

propane dehydrogenation adjacent to domains of $\mathrm{Ni} / \mathrm{Fe}$ alloys for the water dissociation reaction.

Activation energies are plotted as a function of adsorption energies in Figure 10. For propane dehydrogenation, there is almost no change in activation energy. However, for water dissociation, the activation energy decreases substantially as the adsorption energy decreases. Propane is a nonpolar molecule. In contrast, water is a polar molecule. Perhaps the transition state formed from water may be more polarized. The difference in polarization of the molecules being adsorbed may be a part of the explanation for the different relationships between activation energy and adsorption energy.

The improvement obtained with $\mathrm{Ni}-\mathrm{Fe}$ alloys reported here is consistent with two other reports in the literature.

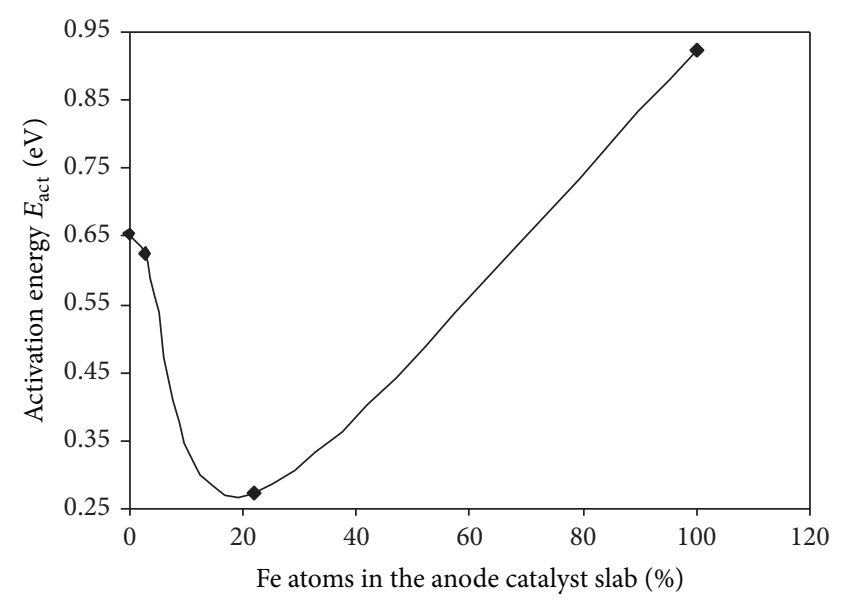

FIGURE 9: DFT calculated activation energy plot, $E_{\text {act }}(\mathrm{eV})$, for water dissociation; ${ }^{*} \mathrm{H}_{2} \mathrm{O} \rightarrow{ }^{*} \mathrm{OH}+{ }^{*} \mathrm{H}$ on $\mathrm{Ni} / \mathrm{Fe}$ anode catalysts of various surface compositions ( $0 \% \mathrm{Fe}, 2.8 \% \mathrm{Fe}, 22.2 \% \mathrm{Fe}$, and $100 \%$ $\mathrm{Fe})$.

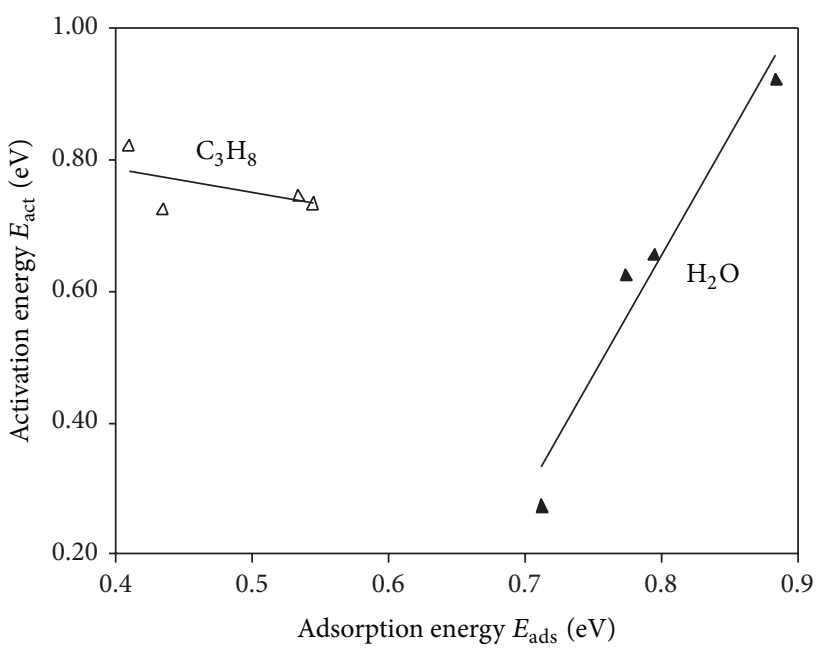

FIGURE 10: Activation energy, $E_{\text {act }}(\mathrm{eV})$, versus adsorption energy, $E_{\text {ads }}(\mathrm{eV})$, for propane dehydrogenation, "open triangles," and for water dissociation, "solid triangles."

DFT computations [41] found that $\mathrm{Ni}$-Fe alloys were superior to pure $\mathrm{Ni}$ for both $\mathrm{CO}$ and $\mathrm{CO}_{2}$ hydrogenation reactions. Experiments [40] also showed that $\mathrm{CO}$ hydrogenation was more superior with $\mathrm{Ni}$-Fe alloys than with pure $\mathrm{Ni}$. It should be noted that both $\mathrm{CO}$ and $\mathrm{CO}_{2}$ are polar molecules as is the $\mathrm{H}_{2} \mathrm{O}$ molecule in this work. Secondly it is known that Pt-Ru alloys are superior to pure Pt [15] for the anode reaction in methanol fuel cells. Pt is in the same column of the periodic table as $\mathrm{Ni}$ and $\mathrm{Ru}$ is in the same column of the periodic table as Fe. Because methanol is a partially oxidized hydrocarbon molecule, the performance of direct methanol fuel cells might be expected to be similar in some ways to direct hydrocarbon fuel cells. 


\section{Conclusions}

The activation energy or barrier height was determined for two reactions in direct hydrocarbon fuel cells. For the water dissociation reaction, a decrease in the activation energy was accompanied by a decrease in the energy of adsorption and by an increase in the $\mathrm{Fe}$ content of $\mathrm{Ni} / \mathrm{Fe}$ alloys. In contrast, the activation energy increased when the $\mathrm{Cu}$ content of $\mathrm{Ni} / \mathrm{Cu}$ alloys increased. For the propane dehydrogenation reaction, the activation energy was almost invariant with the energy of adsorption. The difference in the relationship between activation energy and adsorption energy was attributed to propane being a nonpolar molecule and water being a molecule that can be polarized.

\section{Conflict of Interests}

The authors declare that there is no conflict of interests regarding the publishing of this paper.

\section{Acknowledgments}

The authors are grateful for the financial support from the Canadian Government's Natural Sciences and Engineering Research Council and from the Ontario Provincial Government's Ministry of Research and Innovation (Ontario Fuel Cell Research and Innovation Network).

\section{References}

[1] H. A. Liebhafsky and E. J. Cairns, "The direct hydrocarbon fuel cell with aqueous electrolytes," in Fuel Cells and Fuel Batteries: A Guide to Their Research and Development, pp. 458-521, John Wiley \& Sons, New York, NY, USA, 1968.

[2] J. O. Bockris and S. Srinivasan, "The oxidation of unsaturated hydrocarbons on platinum," in Fuel Cells: Their Electrochemistry, pp. 391-402, McGraw-Hill, New York, NY, USA, 1969.

[3] E. J. Cairns, "Anodic oxidation of hydrocarbons and the hydrocarbon fuel cell," Advances in Electrochemical Sciences and Engineering, vol. 8, pp. 337-392, 1971.

[4] P. Heo, K. Ito, A. Tomita, and T. Hibino, "A proton-conducting fuel cell operating with hydrocarbon fuels," Angewandte Chemie-International Edition, vol. 47, no. 41, pp. 7841-7844, 2008.

[5] E. P. Murray, T. Tsai, and S. A. Barnett, "A direct-methane fuel cell with a ceria-based anode," Nature, vol. 400, no. 6745, pp. 649-651, 1999.

[6] O. Savadogo and F. J. Rodriguez Varela, "Low-temperature direct propane polymer electrolyte membranes fuel cell (DPFC)," Journal of New Materials for Electrochemical Systems, vol. 4, no. 2, pp. 93-97, 2001.

[7] C. K. Cheng, J. L. Luo, K. T. Chuang, and A. R. Sanger, "Propane fuel cells using phosphoric-acid-doped polybenzimidazole membranes," Journal of Physical Chemistry B, vol. 109, no. 26, pp. 13036-13042, 2005.

[8] F. J. R. Varela and O. Savadogo, "The effect of anode catalysts on the behavior of low temperature Direct Propane Polymer Electrolyte Fuel Cells (DPFC)," Journal of New Materials for Electrochemical Systems, vol. 9, no. 2, pp. 127-137, 2006.
[9] T. Hibino, A. Hashimoto, T. Inoue, J. Tokuno, S. Yoshida, and M. Sano, "A low-operating-temperature solid oxide fuel cell in hydrocarbon-air mixtures," Science, vol. 288, no. 5473, pp. 20312033, 2000.

[10] G. Psofogiannakis, Y. Bourgault, B. E. Conway, and M. Ternan, "Mathematical model for a direct propane phosphoric acid fuel cell," Journal of Applied Electrochemistry, vol. 36, no. 1, pp. 115$130,2006$.

[11] H. Khakdaman, Y. Bourgault, and M. Ternan, "Direct propane fuel cell anode with interdigitated flow fields: two-dimensional model," Industrial and Engineering Chemistry Research, vol. 49, no. 3, pp. 1079-1085, 2010.

[12] H. Khakdaman, Y. Bourgault, and M. Ternan, "Computational modeling of a direct propane fuel cell," Journal of Power Sources, vol. 196, no. 6, pp. 3186-3194, 2011.

[13] G. Psofogiannakis, A. St-Amant, and M. Ternan, "Methane oxidation mechanism on $\mathrm{Pt}(111)$ : a cluster model DFT study," Journal of Physical Chemistry B, vol. 110, no. 48, pp. 2459324605, 2006.

[14] S. Vafaeyan, A. St-Amant, and M. Ternan, "Propane fuel cells: selectivity for partial or complete oxidation," Journal of Fuels, vol. 2014, Article ID 485045, 9 pages, 2014.

[15] J. N. Tiwari, R. N. Tiwari, G. Singh, and K. S. Kim, "Recent progress in the development of anode and cathode catalysts for direct methanol fuel cells," Nano Energy, vol. 2, no. 5, pp. 553$578,2013$.

[16] A. Al-Othman, A. Y. Tremblay, W. Pell et al., "Zirconium phosphate as the proton conducting material in direct hydrocarbon polymer electrolyte membrane fuel cells operating above the boiling point of water," Journal of Power Sources, vol. 195, no. 9, pp. 2520-2525, 2010.

[17] A. Al-Othman, A. Y. Tremblay, W. Pell, Y. Liu, B. A. Peppley, and M. Ternan, "The effect of glycerol on the conductivity of Nafion-free ZrP/PTFE composite membrane electrolytes for direct hydrocarbon fuel cells," Journal of Power Sources, vol. 199, pp. 14-21, 2012.

[18] A. Al-Othman, A. Y. Tremblay, W. Pell et al., "A modified silicic acid ( $\mathrm{Si}$ ) and sulphuric acid (S)-ZrP/PTFE/glycerol composite membrane for high temperature direct hydrocarbon fuel cells," Journal of Power Sources, vol. 224, pp. 158-167, 2013.

[19] Z. Liu, L. Ma, J. Zhang, K. Hongsirikarn, and J. G. Goodwin, "Pt alloy electrocatalysts for proton exchange membrane fuel cells: a review," Catalysis Reviews: Science and Engineering, vol. 55, no. 3, pp. 255-288, 2013.

[20] D. C. Higgins and Z. Chen, "Recent progress in non-precious metal catalysts for PEM fuel cell applications," The Canadian Journal of Chemical Engineering, vol. 91, no. 12, pp. 1881-1895, 2013.

[21] S. Stolbov and M. A. Ortigoza, "Rational design of competitive electrocatalysts for hydrogen fuel cells," Journal of Physical Chemistry Letters, vol. 3, no. 4, pp. 463-467, 2012.

[22] F. Tian and A. B. Anderson, "Effective reversible potential, energy loss, and overpotential on platinum fuel cell cathodes," The Journal of Physical Chemistry C, vol. 115, no. 10, pp. 40764088, 2011.

[23] E. Skúlason, V. Tripkovic, M. E. Björketun et al., "Modeling the electrochemical hydrogen oxidation and evolution reactions on the basis of density functional theory calculations," The Journal of Physical Chemistry C, vol. 114, no. 42, pp. 18182-18197, 2010.

[24] Y. Sha, T. H. Yu, B. V. Merinov, P. Shirvanian, and W. A. Goddard, "Oxygen hydration mechanism for the oxygen reduction 
reaction at Pt and Pd fuel cell catalysts," Journal of Physical Chemistry Letters, vol. 2, no. 6, pp. 572-576, 2011.

[25] P. Ferrin and M. Mavrikakis, "Structure sensitivity of methanol electrooxidation on transition metals," Journal of the American Chemical Society, vol. 131, no. 40, pp. 14381-14389, 2009.

[26] T. Zawodzinski Jr., A. Wieckowski, S. Mukerjee, and M. Neurock, "Integrated theoretical and experimental studies of fuel cell electrocatalysts," Electrochemical Society Interface, vol. 16, no. 2, pp. 37-41, 2007.

[27] E. Christoffersen, P. Liu, A. Ruban, H. L. Skriver, and J. K. Nørskov, "Anode materials for low-temperature fuel cells: a density functional theory study," Journal of Catalysis, vol. 199, no. 1, pp. 123-131, 2001.

[28] E. Nikolla, J. Schwank, and S. Linic, "Promotion of the longterm stability of reforming Ni catalysts by surface alloying," Journal of Catalysis, vol. 250, no. 1, pp. 85-93, 2007.

[29] M. B. Vukmirovic, J. Zhang, K. Sasaki et al., "Platinum monolayer electrocatalysts for oxygen reduction," Electrochimica Acta, vol. 52, no. 6, pp. 2257-2263, 2007.

[30] J. K. Nørskov, J. Rossmeisl, A. Logadottir et al., "Origin of the overpotential for oxygen reduction at a fuel-cell cathode," The Journal of Physical Chemistry B, vol. 108, no. 46, pp. 1788617892, 2004.

[31] J. Kua and W. A. Goddard III, "Oxidation of methanol on 2nd and 3rd row group VIII transition metals (Pt, Ir, Os, Pd, Rh, and $\mathrm{Ru}$ ): application to direct methanol fuel cells," Journal of the American Chemical Society, vol. 121, no. 47, pp. 10928-10941, 1999.

[32] J. M. Soler, E. Artacho, J. D. Gale et al., "The SIESTA method for ab initio order-N materials simulation," Journal of Physics Condensed Matter, vol. 14, no. 11, pp. 2745-2779, 2002.

[33] J. P. Perdew, K. Burke, and M. Ernzerhof, "Generalized gradient approximation made simple," Physical Review Letters, vol. 77, no. 18 , pp. 3865-3868, 1996.

[34] W. M. Haynes, CRC Handbook of Chemistry and Physics, CRC Press, 91st edition, 2010.

[35] J. P. Perdew, A. Ruzsinszky, G. I. Csonka et al., "Restoring the density gradient expansion for exchange in solids and surfaces," Physical Review Letters, vol. 100, Article ID 136406, 2008.

[36] D. C. Ford, A. U. Nilekar, Y. Xu, and M. Mavrikakis, "Partial and complete reduction of $\mathrm{O}_{2}$ by hydrogen on transition metal surfaces," Surface Science, vol. 604, no. 19-20, pp. 1565-1575, 2010.

[37] T. Jiang, D. J. Mowbray, S. Dobrin et al., "Trends in CO oxidation rates for metal nanoparticles and close-packed, stepped, and kinked surfaces," The Journal of Physical Chemistry C, vol. 113, no. 24, pp. 10548-10553, 2009.

[38] J. S. Hummelshoj, J. Blomqvist, S. Datta et al., "Communications: elementary oxygen electrode reactions in the aprotic Liair battery," The Journal of Chemical Physics, vol. 132, no. 7, Article ID 071101, 2010.

[39] C. D. Taylor, M. Neurock, and J. R. Scully, "A first-principles model for hydrogen uptake promoted by sulfur on $\mathrm{Ni}(111)$, , Journal of the Electrochemical Society, vol. 158, no. 3, pp. F36F44, 2011.

[40] L. C. Grabow, B. Hvolbæk, and J. K. Nørskov, "Understanding trends in catalytic activity: the effect of adsorbate-adsorbate interactions for CO oxidation over transition metals," Topics in Catalysis, vol. 53, no. 5-6, pp. 298-310, 2010.

[41] J. Sehested, K. E. Larsen, A. L. Kustov et al., "Discovery of technical methanation catalysts based on computational screening," Topics in Catalysis, vol. 45, no. 1-4, pp. 9-13, 2007. 

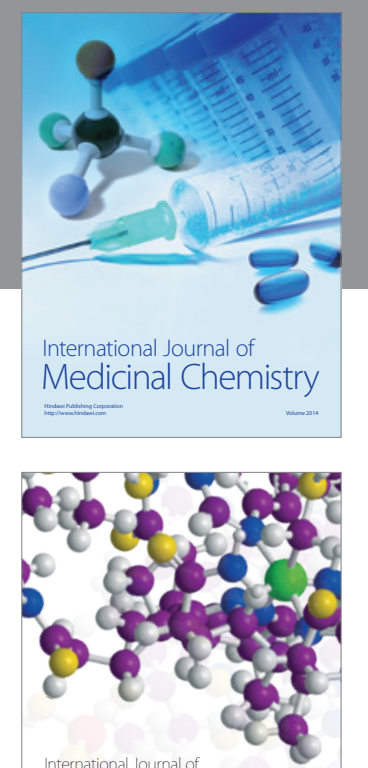

\section{Carbohydrate} Chemistry

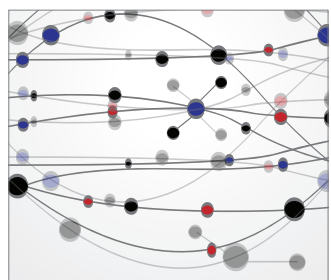

The Scientific World Journal
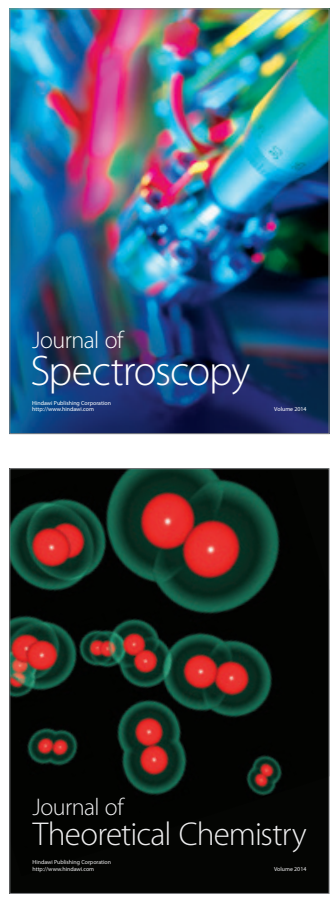
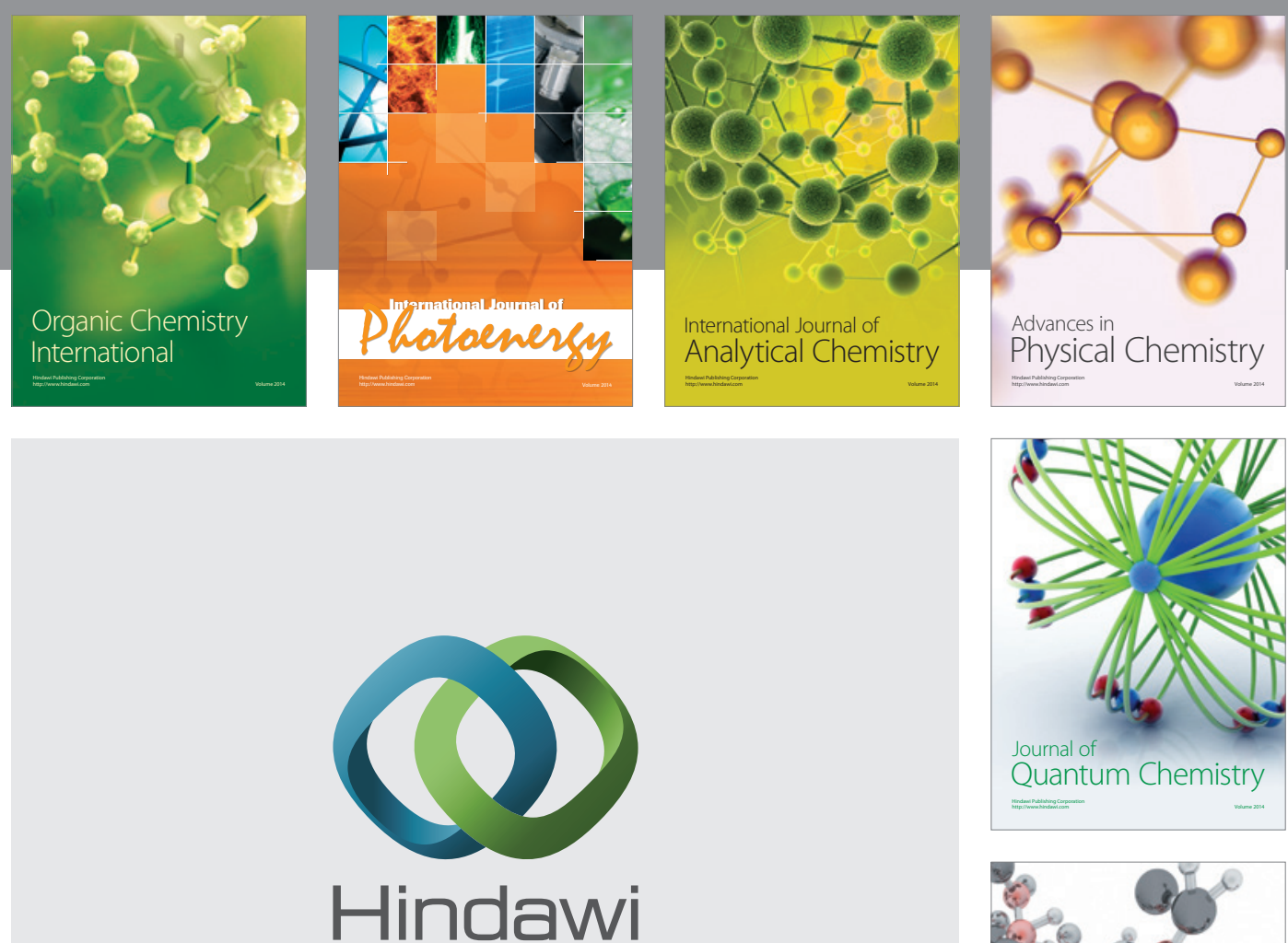

Submit your manuscripts at

http://www.hindawi.com

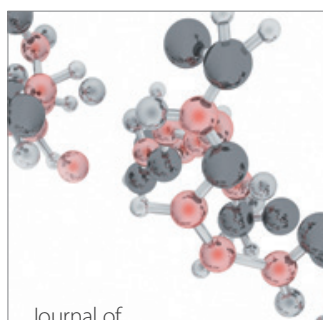

Analytical Methods

in Chemistry

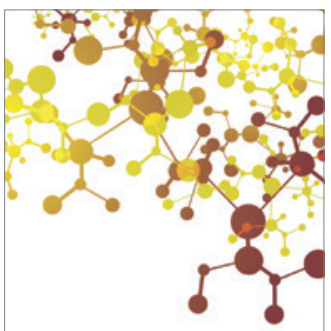

Journal of

Applied Chemistry

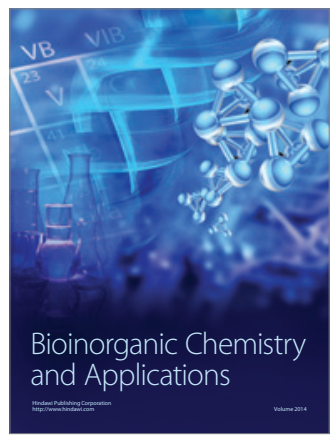

Inorganic Chemistry
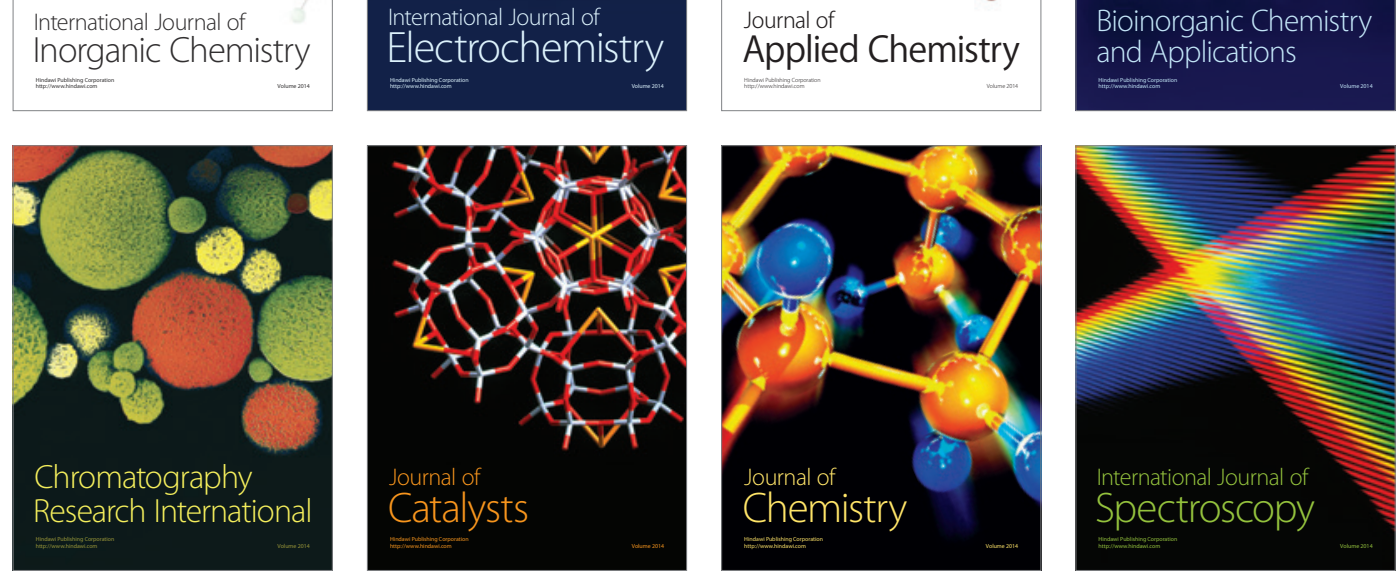